Ewelina Leja

\title{
ATTEMPTS AT DETERMINING REGIONAL FINANCES IN INTERNATIONAL CONVENTIONS
}

Until recently regions were considered to be territorial self-government units governed in accordance with the rules of European Charter of Local SelfGovernment ${ }^{1}$. For some time now the relevance of such an approach has been questioned. Legislative changes in some countries are the instances of this, Poland being the exemplification. In 2006 the Polish translation of the Charter's name was changed from the European Charter of Territorial Self-Government (it relates to all territorial self-government units, also to regions) to the European Charter of Local Self-Government, leaving regions beyond this Charter. Hence, the international definition of the status of regions, including their financial position, has become an important issue.

The first tests in this field were carried out while preparing a draft of the European Charter of Regional Self-Government. The works on this document lasted for three years. Finally, the document was adopted on June 3-5, 1997 in Strasbourg during the Council of Europe's Congress of Local and Regional Authorities of Europe (CLRAE). Therefore, it will be justifiable to discuss the main principles of financing regional self-government within the context of the aforementioned draft of the European Charter of Regional Self-Government first.

In accordance with the Charter's provisions, the financial system of regions shall ensure predictable amounts of public income adjusted to the responsibilities of regions and enabling them to follow their own policy. The sources of regional financing should be sufficiently diverse and flexible so that the regions are given the opportunity to adjust to the general economic development and actual change in the costs of their duties. According to the Charter, the financial resources used for fulfilling their responsibilities shall be derived mostly from their own resources, which shall be freely used by regional authorities. However, as far as their own financial resources are concerned, the taxes and charges which could be collected

1 The European Charter of Local Self-Government prepared in Strasbourg on October 15, 1985. Till 2006 its name was the European Charter of Territorial Self-Government. 
by regions within the scope defined by the constitution or the law were mainly mentioned. In accordance with the provisions of the Charter, the share of regions in general taxes, defined by the constitution or the law, was also included in the foregoing own resources.

Regardless this, the Charter granted regions the right to determine the regional taxes and charges. On the other hand, in the case of the lack of such a possibility, the regions should be authorized, within the frames defined by the constitution or the law, to establish an additional percentage from taxes levied by other public authorities. Moreover, the appropriate procedures of consulting the rules and agreements concerning the division and allocation of the aforementioned resources should be defined. According to the Charter's provisions, administration, comprising of a few levels of authority, or the regional authority could be responsible for the management of the regional taxes, in order to rationalize it and improve its effectiveness and coordination. Obviously, it shall not influence the ownership and usufruct rights. The solidarity principle, included in the Charter, constituted the requirement of introducing, within the limits of each of the countries, the mechanism of financial compensation - accounting for the potential resources as well as the needs of regions, - the objective of which would be the harmonization of the living standards of residents in various regions. As far as the transfers and grants are concerned, the Charter provided that, as a rule, they should be allocated to general purposes, although the financial transfers to regions and the participation in taxes must result from the rules defined in advance, which are based on a few objective criteria connected with the actual needs of the regions. It also gave the regions (within the law limits) an access to capital markets in order to get loans for capital costs (with reservation that they can present their debt service capacity during the debt repayment period using their own revenues). Still, the statutory requirements of compliance with some budgetary provisions or the standard clearing system should not be the limitation for the financial autonomy of the regions. ${ }^{2}$

The aforementioned solutions proposed by the European Charter of the Regional Self-Governments were not accepted by the Member States, including Poland, since in spite of the involvement and optimism during its preparation, the Charter was not ratified, due to rather restrictive character of some solutions, which applied also to the principle of financing regions. Among others, it resulted from Art. 20 (1) of the Charter, according to which, the contracting countries shall be obliged to obey all the Charter's provisions and not to make the supervision of its application difficult. As far as the provisions concerning the financing of regions are concerned, no appeasement in this respect was anticipated. What is more, the lack of precision while formulating particular terms was emphasised. It was underlined that 
the rights guaranteed to the regions by the Charter were also vaguely formulated. Moreover, there was a risk that the document would impose such solutions which would limit the sovereignty of the internal law. These limitations would involve, in particular, the country's competences of shaping the regional relations with other units of country's political system, including public authorities and administration. ${ }^{3}$ The aforementioned and other issues which raise doubts caused that the European Charter of Regional Self-Governments was not ratified by the Council of Europe Member States.

What can be pointed as the second attempt at defining of the statute and their financial position in the international law was the action undertaken to create a new draft of the European Charter of Regional Self-Government, which in short can be called the European Charter of Regional Self-Government-Bis. It was presented on September 15, 2004 by the Committee of Ministers of the Council of Europe in the annex to the "Final Report on the Activities Concerning the Preparation of Various Legal Instruments as regards Regional Self-Government".

This draft varied significantly from the previous European Charter of Regional Self-Governments. Fundamental changes related to the Preamble as well as to the detailed rulings. The new draft included the solutions which were much more moderate than the previous Charter of 1997 with regard to the issue of definitions as well as the prerogatives of the regional self-government or the financial system itself. The provisions on the issues of financing regions, were formulated in only one article - Art. 16. The whole structure of Article 16, which was dedicated precisely to the financial resources of the regional self-government, compensation and transfers was modelled on eight points of Art. 9 of the European Charter of the Local SelfGovernments. Only, the two first points of this article were of the obligatory character. ${ }^{4}$ It was also characteristic that the draft did not use the concept 'own resources' directly, in spite of the obligation of ensuring financial autonomy for the regions on the basis of proposed funds - it was indicated by the provisions of Art. 16 of the Charter, in paragraph 1 in particular. According to its content, regional community should have at their disposal public funds adjusted to their responsibilities, which enable them to prepare activities as regards their competences. Paragraph 2 of the quoted article, which developed the thought, gave the regional communities the right to manage their funds freely while performing tasks with regard to their competences. Having said that it should be noted that in accordance with the content of Article 16, at least some of the regional communities funds should be derived from taxes and regional charges, the amounts of which shall be decided by regional communities within the limits provided for by the act. These funds could cover the shares in taxes 
constituting the country's revenue which were not purposeful subsidies, thus having a predefined allocation. ${ }^{5}$

While analysing the draft of the European Charter of Regional Self-GovernmentsBis we may notice that it dispelled some doubts which appeared with reference to the European Charter of Regional Self-Governments of 1997. However, it did not give the basis for the international acceptance. Therefore, during the Congress of Ministers responsible for the local and regional democracy, which took place in 2005 in Budapest, it was officially rejected. Due to these circumstances the decision to prepare a new Charter draft from the scratch was taken.

The new draft entitled the European Charter of Regional Democracy was submitted for discussion and to consultation on May 15, 2007, as a result of reopening of discussion on European legal instruments concerning regionalization. The new document resulted from the necessity of quick and sudden changes, not only in communities but also in their political structures and management methods. This innovative approach was created to gain international acceptance for that new legal instrument concerning regional democracy.

Between May 27-29, 2008 in Strasburg, the Congress of Local and Regional Authorities of the Council of Europe adopted a draft of the European Charter of Regional Democracy with the assumption that after acceding of five Member States of the European Council, it will become the binding international convention and it will be possible to recommend its adoption by all the Member States of this organization.

This draft of regional 'constitution' is composed of a preamble and four parts (part I - "Key elements of regional democracy"; part II - without the specified title; part III - "Forms of regional organization"; part IV - "Final provisions"). The provisions of Art. 1 of the Charter have crucial significance for the content and obligations of the adopting countries. They state that:- all the provisions of part I of the Charter are obliging - one of the eventualities provided for by points a, b or c of Art. 23-28 shall be selected from the part II of the Charter; - from part III of the Charter at least 27 from included there 41 paragraphs shall be chosen. Articles which are not divided into paragraphs are treated as a single paragraph. The paper under consideration relates exclusively to the financial issues and excludes the holistic presentation of the Charter's content. However, it should be kept in mind that also the remaining rules influence the financial principles (e.g. organizational, constitutional, etc.) - therefore, while assessing and choosing provisions concerning regional finances, the entirety of the Charter's provisions shall be taken into requirements of the Council of Europe, in: E. Chojna - Duch (eds.), Current problems of local and regional finances in Poland and other EU countries, Warsaw 2006, p. 35 and the next. 
consideration. As far the solutions which relate to the regional finances directly, it should be noted what follows:

1) Part I Art. 16 of part 7 is devoted to these issues ("Regional Revenue Sources") and has to be adopted in its entirety by the countries ratifying the Charter. The provisions are the following:

- regions shall have property rights;

- regions have the right to administer the sources of revenue provided for by the law, predictable, and sufficient for the effective executing of their competences and responsibilities;

- the sources of the revenue of regions shall be sufficiently varied. On one hand, they should ensure the rational stability and on the other hand, shall ensure real evolution in relation to the costs involved in the performed function;

- financial transfers for the benefit of regions shall be regulated by statutory provisions based on the objective tests connected with regional responsibilities;

- transfers of responsibilities for the benefit of regions shall be accompanied by appropriate transfers of funds;

- as a general rule a country does not define the allocation of loans transferred to regions.

2) In part II of the Charter, which is based on selecting one of three possible solutions, Art. 25 ("Revenue Sources") is related directly to regional finances. The solutions are the following:

- revenue sources of regions and conditions of their exploitation are specified in the constitution;

- regions shall have at their disposal the revenue sources which can be utilized independently. The substantial part of the revenue shall be derived from taxes and charges, the amount of which is determined by a region within the limits specified by the law;

- revenue sources of a region and conditions of their exploitation are specified by the law or a statute. The revenue may include contributions from local unions which are a part of regions.

3) Part III of the Charter includes 12 principles relating directly to regional finances (Art. 34 to 37). Having regard to the fact that the countries adopting the Charter have to choose at least 27 out of 41 regulations presented in this part, it can be assumed that a country ratifying the Charter may adopt all or 
none of the proposed financial provisions, however, this possibility is not a very realistic one.

Article 34 of the Charter, concerning the application of correlation principle, provides for four possibilities.

- a rule according to which the revenue resources should be proportional to their responsibilities and shall be sufficient for the effective carrying out responsibility, ought to be recorded in the constitution or a statute;

- losses in regional revenue resulting from a decision of authorities concerning annulling or reducing regional taxes, shall be compensated by means of stable, adequate and equivalent revenues;

- in case of the transfer of a new responsibility, transferred revenue shall be at least of the amount equivalent to these exploited earlier for the realization of the objective tasks; the revenue shall provide for funds, property and/or employees;

- an obligation to transfer the adequate revenue or grant entirely new revenue shall also provide for decisions resulting from fluctuation of indicators of general costs such as salaries, national insurance contribution or environmental protection norms.

Article 35 of the European Charter for Regional Democracy refers to own revenue of regions while offering two possible provisions:

- substantial part of regions revenues shall be derived from charges that can be introduced individually and from regional taxes (exclusive and joint) the amount of which is generally defined by a region, and in particular cases within the limits provided for by the law.

- own resources shall be sufficient for the effective carrying out of regional responsibilities resulting from their competences.

Article 36 of the Charter is devoted to global and specific subsidies. If one would like to refer to Polish terminology, they shall be translated as subventions and grants. The article includes three types of provisions:

- principles of subventions and grants shall guarantee economic and financial stability of regions and shall take into account such criteria as economic growth, costs increase, increase in salaries and evolution of minimum subsistence level and environmental protection;

- grants for regions allocated for financing specific projects shall be limited and shall concern mainly investments and delegated responsibility; 
- if subventions and grants are conditioned by the participation of regions, the level of this participation shall take into consideration financial abilities of regions.

Article 37 of the Charter is dedicated to financial compensation. In this respect, three solutions are anticipated:

- the aim of financial compensation is to reduce, on one hand the differences resulting from structural factors of regions, and on the other the differences between regions as regards global financial abilities.

- criteria and procedures of compensation are specified by the law and shall be objective, clear, transparent, predictable, real and non-discriminatory.

- compensation procedures shall lead to flexible level of compensation, shall not make the realization of regional autonomy difficult and shall not prevent unrestrained administration of regions.

If the presented solutions of the European Charter of Regional Democracy are compared with corresponding solutions of the European Charter of Regional SelfGovernment or European Charter of Regional Self-Government-Bis, the fundamental change of philosophy and content of provisions is visible. It is because the draft of the European Charter of Regional Democracy adopts solutions which are much more universal and less restricting, whereas in relation to more detailed solutions it gives ratifying countries a possibility of flexible choice of solutions which are the most appropriate for them. It gives the realistic hope that the European Charter for Regional Democracy will come into force soon and that it will play a role of "constitution" in harmonious development of regionalism in Europe. 


\section{Streszczenie}

Do niedawna uznawano, że regiony jako jednostki samorządu terytorialnego objęte są zasadami Europejskiej Karty Samorządu Terytorialnego ${ }^{6}$. Od pewnego czasu zgłaszane są wątpliwości czy jest to podejście zasadne. Przykładem tego są pewne zmiany legislacyjne niektórych państw, czego egzemplifikacją jest Polska. W 2006 r. zostaje zmieniona nazwa Europejskiej Karty Samorządu Terytorialnego (odnosi się to do wszystkich JST, także regionów) na nazwę Europejska Karta Samorządu Lokalnego, pozostawiając regiony poza tą Kartą. W tej sytuacji ważną sprawą staje się międzynarodowe określenie statutu regionów, w tym ich pozycji finansowej. Wobec powyższego zasadnym jest podjęcie próby określenia finansów regionalnych w konwencjach międzynarodowych. 